\title{
PERSPEKTIF REMAJA TENTANG KESEHATAN REPRODUKSI SEBAGAI UPAYA PENCEGAHAN PENYIMPANGAN PERILAKU SEKSUAL DI KABUPATEN BEKASI
}

\author{
Maesaroh $^{1)}$, Eka Kartikawati' ${ }^{2)}$, Devi Anugrah ${ }^{3)}$ \\ ${ }^{1,2,3)}$ Pendidikan Biologi Universitas Muhammadiyah Prof. Dr. HAMKA, \\ email:maesyaroh@uhamka.ac.id
}

\section{Diterima 30 Maret 2019 disetujui 5 Mei 2019}

\begin{abstract}
Indonesia's demographic data shows that the percentage of young people over $20 \%$ or about 60 million Indonesians is at a young age. This potential greatly determines the progress and character of the nation in the future. The swift influence of globalization through the media has a positive and negative impact on the growth and behavior development of the younger generation. One of the negative impacts facilitated by the spread through the media was deviant behavior that occurred in various parts of the world which was later imitated by young people in Indonesia. Drug abuse, sexual behavior outside of marriage and sexual orientation deviation or known as LGBT (Lesbian, Gay, Bisexual, Transgender). This study aims to detect the opinions and understanding of adolescents about the importance of healthy reproduction as an effort to prevent early sexual behavior deviations. The study population was middle school students in Bekasi Regency, as many as six sample schools were selected using the random sampling technique. The research method used is descriptive quantitative. The results showed that $70 \%$ of female adolescents in Bekasi maintain their reproductive health behaviors while $57 \%$ of men pay attention to their reproductive health behavior. The results of adolescent sexual deviation behavior from this study were as many as $10.9 \%$ of teenagers had masturbation, and there were $5.1 \%$ of teens wanting same-sex lovers.
\end{abstract}

Keywords: Adolescents, Reproductive health, Sexual Behavior Deviations

\section{PENDAHULUAN}

Menurut WHO, remaja ialah mereka yang berusia 10-19 tahun. PBB menyatakan anak muda untuk usia 15-24 tahun. Hal ini kemudian disatukan dalam terminologi kaum muda yang mencakup usia 10-24 tahun. Masa remaja diwarnai oleh pertumbuhan, perubahan, munculnya berbagai kesempatan, dan seringkali menghadapi resiko-resiko kesehatan reproduksi. Sekitar satu milyar manusia adalah remaja, hampir satu dari enam manusia di bumi dan $85 \%$ diantaranya hidup di Negara berkembang (UNFPA, 2000). Banyak sekali remaja yang sudah aktif secara seksual (walau terkadang tidak atas piihanya sendiri), dan di berbagai daerah separuh dari mereka sudah menikah. Kegiatan seksual menempatkan remaja pada resiko terhadap berbagai masalah kesehatan reproduksi. Setiap tahun sekitar 15 juta remaja berusia 15-19 tahun melahirkan, 4 juta lainnya melakukan aborsi, dan hampir 100 juta remaja terinfeksi penyakit menular seksual (PMS) yang dapat disembuhkan.

Resiko kesehatan yang dihadapi remaja dipengaruhi oleh berbagai faktor yang saling berhubungan misalnya tuntutan untuk kawin muda dan hubungan seksual, akses terhadap pendidikan dan pekerjaan, ketidaksetaraan jender, kekerasan seksual, dan pengaruh media massa maupun gaya hidup yang populer. Remaja seringkali kekurangan informasi dasar tentang kesehatan reproduksi, keterampilan menegoisasi hubungan seksual, dan akses terhadap pelayanan 
kesehatan reproduksi yang terjangkau dan terjamin kerahasiaannya. Keprihatinan akan jaminan kerahasiaan atau kemampuan membayar dan kenyataan ataupun persepsi remaja terhadap sikap tidak senang yang ditunjukkan oleh petugas kesehatan semakin membatasi akses pelayanan lebih jauh meksi pelayanan itu ada. Banyak diantara remaja yang kurang atau tidak memiliki hubungan yang stabil dengan orangtuanya maupun orang dewasa lainnya.

Munculnya banyak kesempatan dan resiko permasalahan kesehatan reproduksi yang dihadapi kaum muda mendorong peneliti untuk melakukan penelitian lapangan dengan judul "Perspektif Kalangan Muda Tentang Kesehatan Reproduksi sebagai Upaya Pencegahan Dini Penyimpangan Perilaku Seksual Di SMA dan SMK Kabupaten Bekasi" dengan tujuan untuk mendeteksi gejala penyimpangan perilaku seksual pada remaja peserta didik sekolah menengah sekabupaten bekasi. Melalui penelitian ini akan diperoleh data berupa komunitas (sekolah) dengan peserta didik yang rentan mengalami resiko kesehatan reproduksi.

\section{METODE}

Metode yang dilakukan dalam penelitian ini yaddeskriptif kuantitatif, suatu pendekatan yang memungkinkan dilakukan pencatatan data primer hasil peneltian dalam bentuk angka atau numerical sehingga dapat memudahkan proses analisis dan pemaknaan. Teknik pengumpulan data dilakukan secara triangulasi (gabungan), analisis data bersifat induktif, dan hasil penelitian menekankan pada makna dan generalisasi. Data penelitian diperoleh dari survey pendapat atau persepsi peserta didik SMA dan SMK di Kabupaten Bekasi mengenai kesehatan reproduksi dan deteksi pola perilaku penyimpangan seksual.

\section{HASIL DAN PEMBAHASAN \\ Hasil Kuesioner Perilaku Kesehatan Reproduksi Remaja}

Hasil kuesioner perilaku kesehatan reproduksi pada remaja dibedakan berdasarkan gender peremuan dan laki-laki sebagai berikut:

\section{Remaja Perempuan}

Perilaku kesehatan reproduksi pada remaja perempuan dalam penelitian ini diukur melalui 10 jenis pernyataan tentang perilaku kesehatan reproduksi remaja perempuan yang dilakukan dalam kesehariannya. Responden yang mengisi data kuesioner terdapat 104 siswi dari berbagai sekolah di Bekasi. Hasil perbandingan kuesioner perilaku kesehatan reproduksi remaja perempuan yang meliputi 10 pernyataan divisualisasikan dalam diagram gambar 1 .

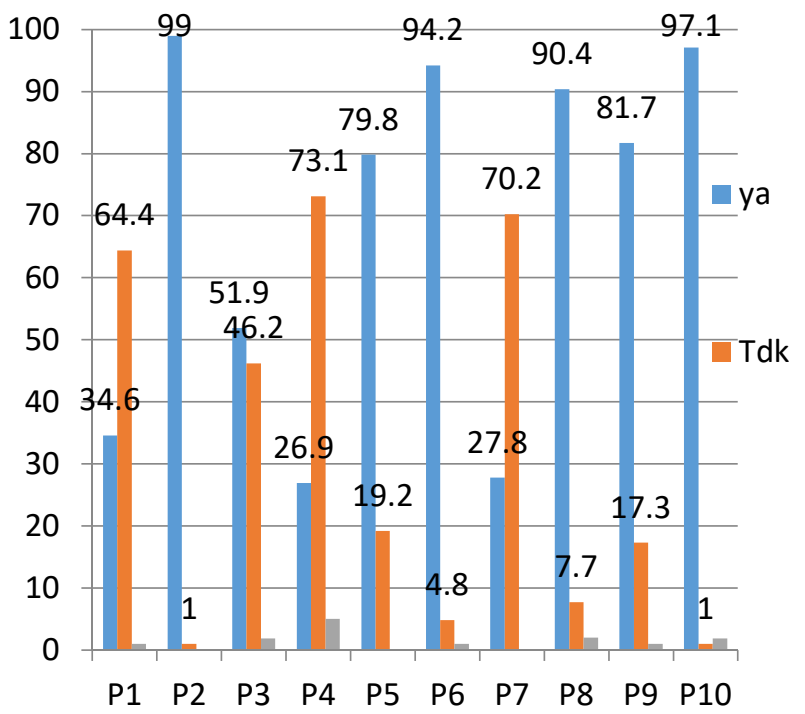

Gambar 1. Pernyataan Perilaku Kesehatan Reproduksi Remaja Perempuan

Berdasarkan gambar 1, dapat diketahui hasil kuesioner perilaku kesehatan reproduksi remaja perempuan yaitu pada pernyataan 1 tentang 
membersihkan bagian vital dengan menggunakan sabun ber $\mathrm{PH}$ tinggi $(34,6 \%)$, pernyataan 2 tentang membersihkan alat kelamin setelah buang air kecil dan buang air besar dengan air bersih (99\%), pernyataan 3 tentang mengganti pembalut 4-5 kali dalam sehari pada saat menstruasi $(51,2 \%)$, pernyataan 4 tentang penggunaan pakaian dalam yang terbuat dari bahan karet $(26,9 \%)$, pernyataan 5 tentang penggunaan pakaian dalam yang terbuat dari bahan katun $(79,8 \%)$, pernyataan 6 tentang mengganti pakaian dalam jika basah $(94,2 \%)$, pernyataan 7 tentang pemeriksaan rutin ke dokter untuk deteksi dini kanker organ reproduksi $(27,8 \%)$, pernyataan 8 tentang selalu membersihkan alat kemaluan setelah BAB mulai dari depan ke belakang $(90,4 \%)$, pernyataan 9 tentang selalu mengeringkan alat kemaluan setelah $\mathrm{BAK}$ atau $\mathrm{BAB}$ dengan handuk kering dan bersih atau tisu $(81,7 \%)$, pernyataan 10 tentang selalu mencuci tangan sebelum dan sesudah BAK atau BAB $(97,1 \%)$. Pada pernyataan kuesioner perilaku kesehatan reproduksi remaja perempuan ada beberapa pernyataan yang tidak dijawab oleh responden kecuali pada pernyataan no 4 dan 7 . Terdapat 3 pernyataan yang hasilnya dibawah $50 \%$, maka dari itu sekitar $70 \%$ remaja perempuan di daerah Bekasi menjaga perilaku kesehatan reproduksinya masing-masing.

\section{Remaja Laki-Laki}

Perilaku kesehatan reproduksi pada remaja laki-laki pada penelitian ini diukur melalui 7 jenis pernyataan kesesuaian tentang perilaku kesehatan reproduksi remaja laki-laki yang dilakukan dalam kesehariannya. Responden yang mengisi data kuesioner yaitu 71 siswa dari berbagai sekolah di Bekasi. Hasil perbandingan kuesioner perilaku kesehatan reproduksi remaja perempuan yang meliputi 7 pernyataan divisualisasikan dalam diagram batang yang disajikan pada gambar berikut:

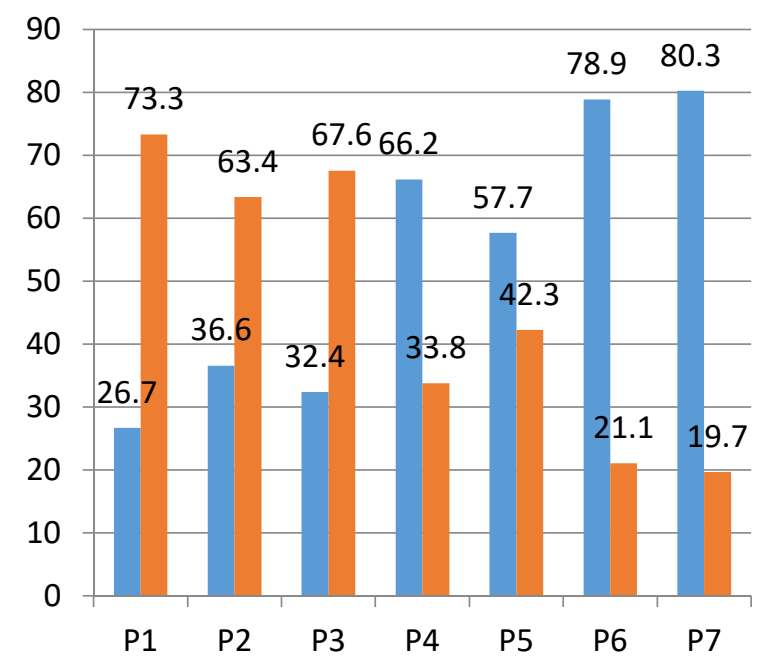

Gambar 2. Perbandingan Pernyataan Perilaku Kesehatan Reproduksi Remaja Laki-laki

Berdasarkan grafik gambar 2 dapat dilihat hasil Kuesioner Perilaku Kesehatan Reproduksi Remaja laki-laki yaitu pada pernyataan 1 tentang selalu merapihkan rambut kelamin disekitar penis $(26,7 \%)$, pernyataan 2 tentang penggunaan pakaian dalam yang ketat untuk menyokong penis $(36,6 \%)$, pernyataan 3 tentang selalu melakukan pemeriksaan ke dokter kulit dan kelamin jika terdapat luka dan lecet pada testis $(32,4 \%)$, pernyataan 4 tentang sering mengobati sendiri apabila di daerah testis terasa gatal $(66,2 \%)$, pernyataan 5 tentang selalu menggunakan pakaian dalam yang tidak ketat untuk melancarkan peredaran darah pada penis $(57,7 \%)$. pernyataan 6 tentang selalu membersihkan alat kemaluan setelah BAB mulai dari depan ke belakang (78,9\%), pernyataan 7 tentang selalu mengeringkan alat kemaluan setelah BAK atau BAB dengan handuk kering dan bersih atau tisu (80,3\%). 7 pernyataan yang dibaerikan hanya 3 pernyataan yang dibawah $50 \%$ maka sekitar 57\% siswa laki-laki yang ada 
dibekasi memperhatikan perilaku kesehatan reproduksinya.

\section{Hasil Kuesioner Perilaku Penyimpangan Seksual Remaja}

Data Hasil penelitian ini diperoleh untuk mengetahui perilaku penyimpangan seksual remaja perempuan dan juga laki-laki. Pertanyaaan keseluruhan terdapat 10 pertanyaan jika diuraikan maka 8 pertanyaan untuk semua jenis kelamin dan sisa 1 pertanyaan khusus untuk perempuan tentang menstruasi dan 1 lagi pertanyaan khusus untuk laki-laki tentang mimpi basah. Hasil untuk setiap pertanyaan dapat dilihat pada gambar 3 .

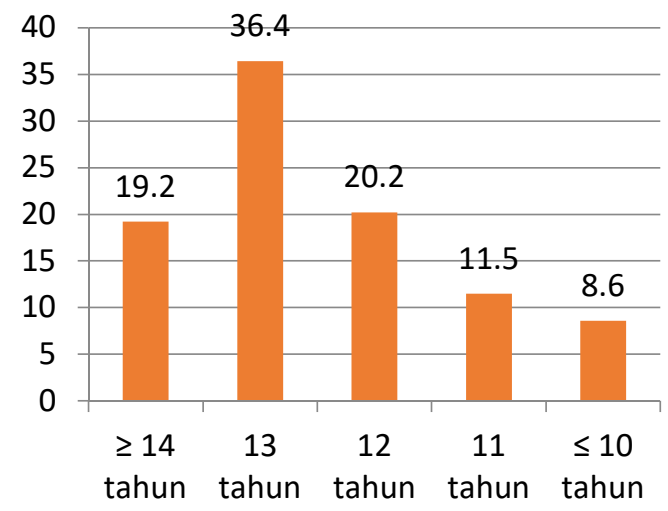

Gambar 3. Data Hasil Usia Pertama Menstruasi pada Perempuan

Berdasarkan grafik di atas diketahui persentase yang paling banyak pada saat siswi pertama kali mengalami menstruasi adalah saat usia mereka 13 tahun sebanyak $36,4 \%$, kemudian $20,2 \%$ pada usia siswa 12 tahun, $19,2 \%$ pada usia $\geq$ 14 tahun, $11,5 \%$ pada usia 11 tahun dan yang paling sedikit yakni $8,6 \%$ pada usia $\leq 10$ tahun. Data penelitian kedokteran memang benar rata-rata usia menstruasi pertama dimulai umur 9-14 tahun. usia menstruasi pertama dapat terjadi berbedabeda seperti dijelaskan Dokter Spesialis Kebidanan dan Kandungan Center for
Sexual Health and Education, AS, Mauren Whelihan bahwa faktor lingkungan dan berat badan dapat mempengaruhi kapan seorang perempuan menstruasi pertama. Ciri pubertas pada perempuan dengan mengalami menstruasi sedangkan pada laki-laki dengan mengalami mimpi basah. Hasil penelitian usia pertama kali laki-laki mengalami mimpi basah pada responden remaja laki-laki di Bekasi dapat dilihat pada gambar 4.

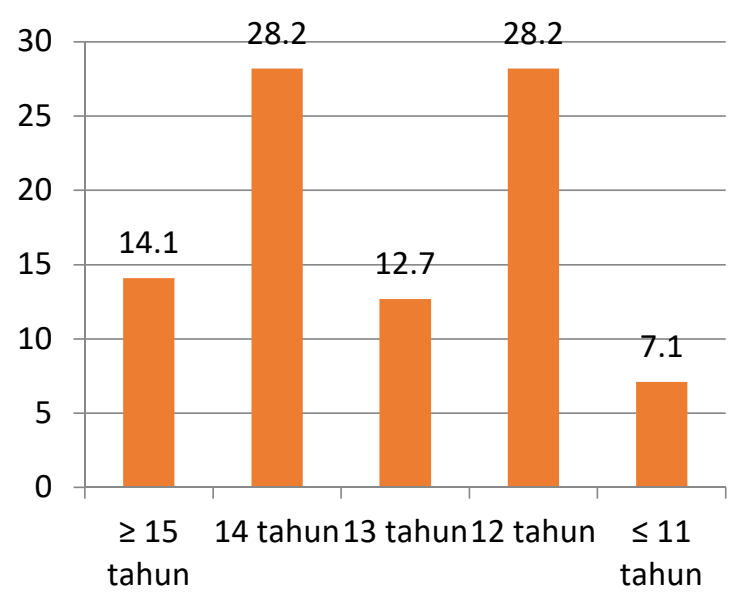

Gambar 4. Data Hasil Usia Pertama Mimpi Basah

Berdasarkan gambar 4 diketahui persentase yang paling banyak pada saat siswa pertama kali mengalami mimpi basah pada usia 14 tahun dan 12 tahun sebanyak $28,2 \%$ kemudian $14,1 \%$ pada usia $\geq 15$ tahun, $12,7 \%$ pada usia 13 tahun dan 7,1\% pada usia $\leq 11$ tahun. Mimpi basah ini sebagai tanda seseorang mengawali masa menuju remajanya, dan saat ini tumbuh maka mereka sudah mulai memproduksi hormone yang bernama testoteron yang nantinya akan menghasilkan sejumlah sperma yang subur dan sehat. Rata-rata remaja lakilaki mengalami mimpi basah pada usia 13-17 tahun. 


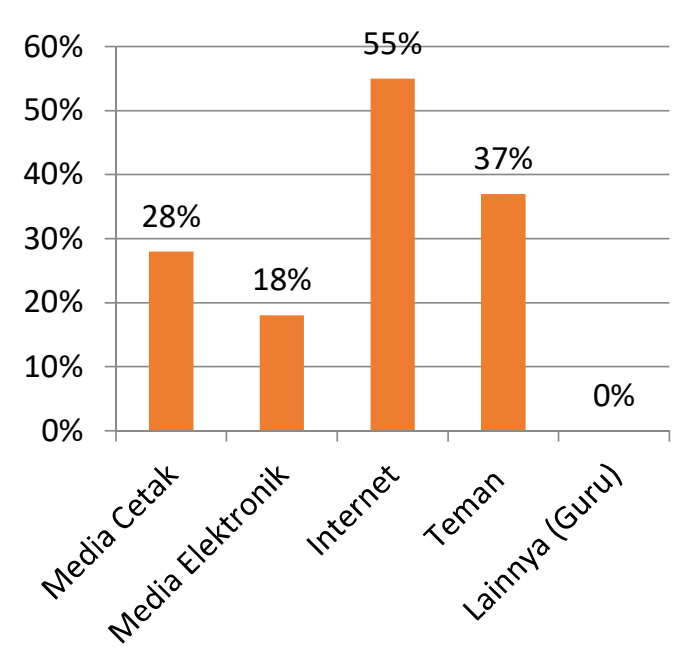

Gambar 5. Sumber Informasi tentang Seks yang diperoleh Responden

Sumber informasi tentang seks yang didapatkan oleh responden berasal dari berbagai sumber seperti gambar 5 . Hasil dalam penelitian ini ternyata sumber informasi tertinggi diperoleh melalui internet sebesar 55\% kemudian 37\% dari teman, $28 \%$ media cetak, $18 \%$ media elektronik dan lainnya dalam hal ini dari guru sebesar $8,6 \%$. Persentase sumber informasi melalui internet paling besar karena pada saat ini perkembangan media online sudah sangat pesa, sehingga berbagai informasi dapat diperoleh dengan mudah dan cepat.

Responden yang terdiri dari siswa dan siswi juga menjawab pertanyaan tentang pacar yang dimiliki saaat ini, dari 175 orang responden $88 \%$ memiliki pacar, $10,3 \%$ tidak memilik pacar dan $1,7 \%$ menyatakan bahwa mereka belum pernah memiliki pacar sebagaimana gambar 6 .

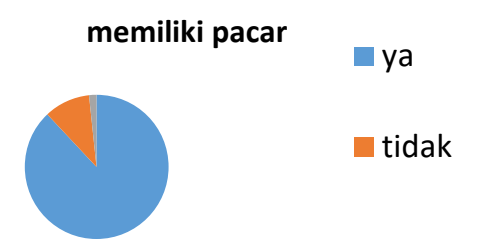

Gambar 6. Persentase Memiliki Pacar
Hasil dari pertanyaan mengenai usia pertama kali pacaran, ternyata berbagai macam usia yang telah di alami responden yakni sebesar 23,4\% pertama kali pacaran pada saat usia 13 tahun, $22,9 \%$ saat usia 14 tahun, $16 \%$ saat usia 15 tahun, $8,6 \%$ saat usia 11 tahun, $8 \%$ pada usia 12 tahun dan 16 tahun serta $5,7 \%$ saat usia 10 tahun. Jika dilihat dari banyaknya jumlah berpacaran maka 44,6\% mereka sudah pernah berpacaran 1 sampai 3 kali, 28\% (4 sampai 6 kali), 6,3\% (10 sampai 12 kali). 3,4\% (7sampai 9 kali), 2,9\% (13 sampai 15 kali) dan 1,7\% sebanyak 16-19 kali berpacaran. Data hasil mengenai usia pertama kali berpacaran dapat dilihat pada Gambar 7 . data lebih rinci jumlah berpacaran dapat dilihat pada Gambar 8.

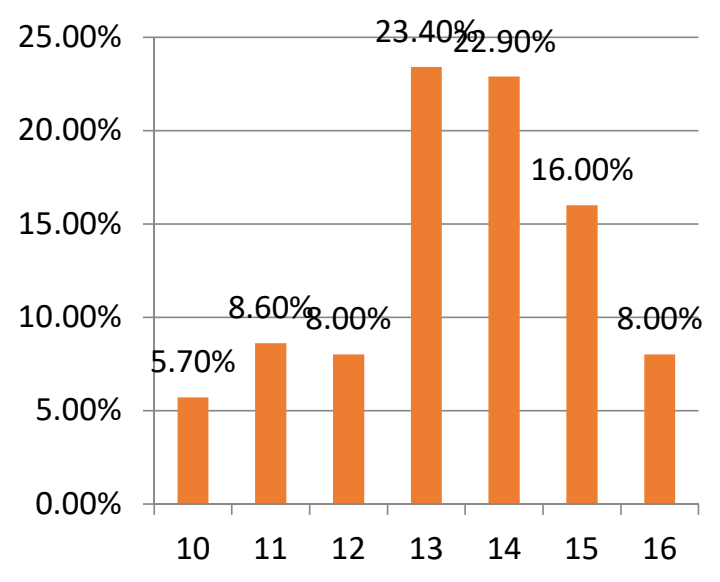

Gambar 7. Data Usia Pertama Kali Pacaran

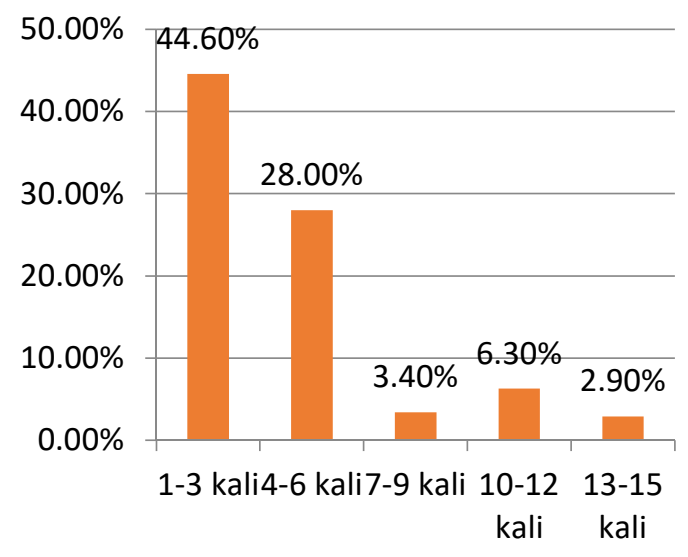

Gambar 8. Data Jumlah Berpacaran 
Pertanyaan selanjutnya mengenai lama bertemu pacar $33,1 \%$ selama 2 jam, $28,6 \%$ selama 1 jam, 8,6\% 3 jam, 2,9\% 4 jam, $8 \% 5$ jam, 2,9\% $\leq 6$ jam dan $0.5 \% 6$ jam. Lokasi menghabiskan waktu dengan pacar sebesar 51,4\% dirumah dan yang paling rendah 3,4\% menghabiskan waktu keliling-keliling dengan mobil tanpa tujuan. Data mengenai lama bertemu pacar dapat diketahui pada Gambar 9. dan hasil data mengenai lokasi untuk menghabiskan waktu dengan pacar dapat dilihat pada Gambar 10.

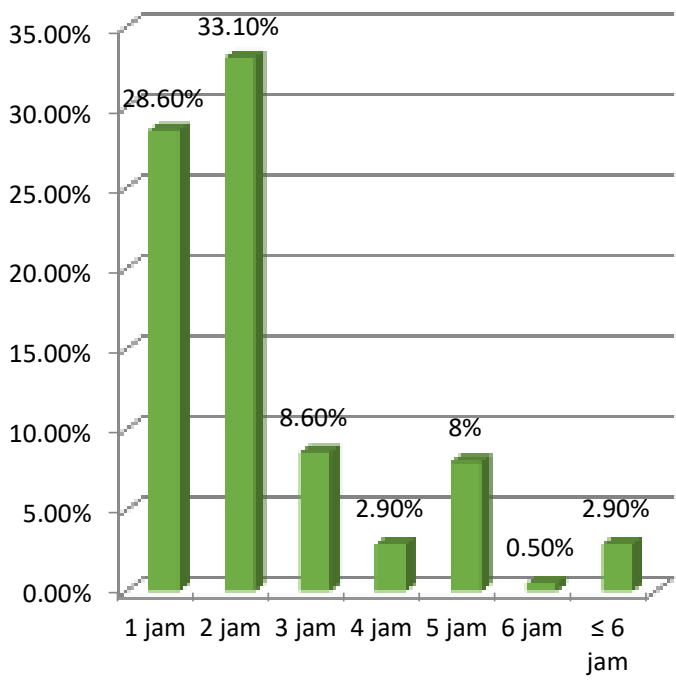

Gambar 9. Data Lama Waktu Bertemu Pacar

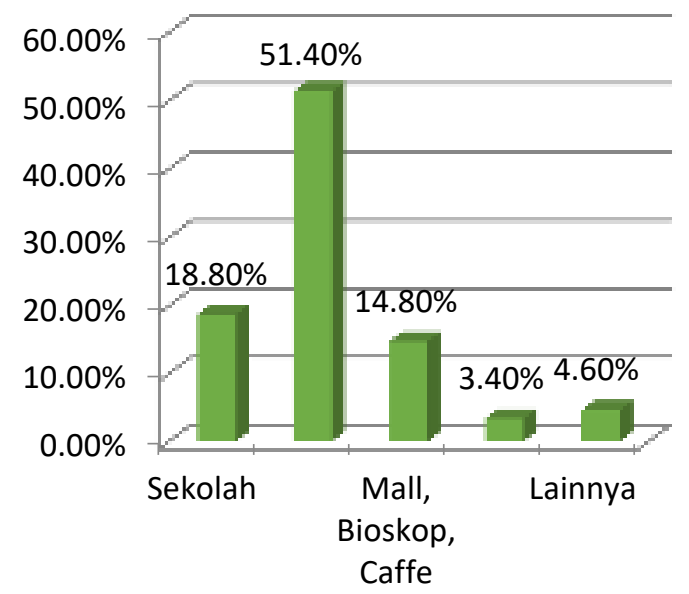

Gambar 10. Data Lokasi Berpacaran
Pertanyaan berikutnya yaitu apakah responden baik siswa mupun siswi pernah melakukan onani atau masturbasi? hasilnya $82,3 \%$ tidak pernah melakukan, $10,9 \%$ pernah melakukan dan $6,8 \%$ tidak menjawab. Reponden yang tidak menjawab kemungkinan karena tidak mengerti tentang apa yang dipertanyakan atau mereka absent. Hasilnya ini dapat dilihat pada gambar 11.

\section{pernah melakukan onani/masturbasi}

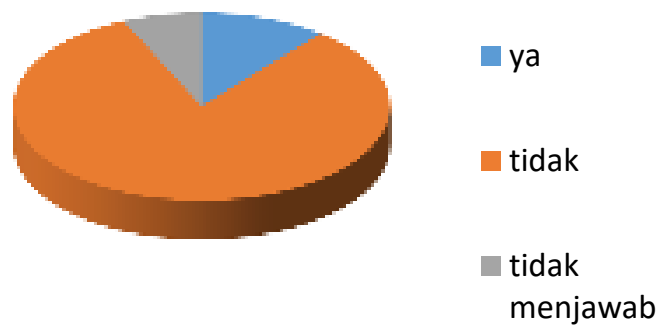
Gambar 11. Persentase Pernah Melakukan
Onani/Masturbasi

Pertanyaan terakhir membahas tentang apakah responden pernah menginginkan mempunyai pasangan yang sesama jenis $91,4 \%$ tidak. 5,1\% menjawab menginginkan dan 3,5\% tidak menjawab.

\section{menginginkan kekasih sesama jenis}

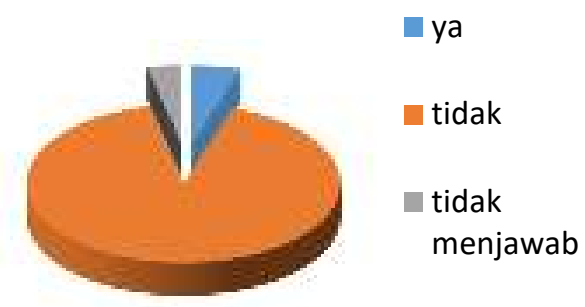

Gambar 12. Persentase Menginginkan Kekasih Sesama Jenis 


\section{Perilaku Kesehatan Reproduksi Perilaku Penyimpangan Seksual Remaja Remaja}

Pengetahuan tentang perilaku kesehatan reproduksi sangat mempengaruhi perilaku seksual pranikah pada remaja, jika perilaku kesehatan reproduksi pada remaja tidak memiliki pengetahuan yang baik maka dapat menyebabkan dampak buruk pada remaja. Kesehatan reproduksi dapat dimulai sejak dini dari diri sendiri tentang kebiasaan-kebiasaan yang dilakukan dalam kehidupan sehari-hari, karena mulai dari situ kita dapat terhindar dari perilaku penyimpangan seksual. Berdasarkan hasil penelitian yang telah diperoleh $70 \%$ remaja perempuan atau siswi di daerah Bekasi menjaga perilaku kesehatan reproduksinya masing-masing sedangkan $57 \%$ siswa laki-laki yang ada di Bekasi memperhatikan perilaku kesehatan reproduksinya. Berdasarkan hasil tersebut maka hasil yang didapatkan mengenai perilaku kesehatan reproduksi siswa-siswi di bekasi sudah baik. Pendidikan perilaku kesehatan reproduksi memang harus diberikan secara akurat dan benar kepada remaja, dapat di mulai dari lingkungan keluarga misalnya orang tua yang memberikan informasi professional dan terbuka atau pun dari sekolah yang memberikan pendidikan seksual berbasis sekolah karena dari hasil penelaahan 35 penelitian di negara maju dan berkembang menyimpulkan, pendidikan seksual berbasis sekolah yang diberikan didalam kurikulum pendidikan maka tidak menyebabkan terjadi hubungan seksual lebih dini dan juga tidak menyebabkan bertambahnya kegian seksual remaja (Notoatmodjo, 2007).
Pada kehidupan psikis remaja, perkembangan organ seksual mempunyai pengaruh kuat dalam minat remaja terhadap lawan jenis. Ketertarikkan antar lawan jenis ini kemudian berkembang ke pola yang lebih serius serta memilih pasangan yang akan ditetapkan sebagai teman hidup. Dalam hal ini berdasarkan hasil penelitian yang telah dilakukan ternyata remaja-remaja siswa-siswa sekolah menengah atas sudah mempunyai pacar dari usia yang 10 tahun $(5,7 \%)$ dan sudah beberapa kali mempunyai pacar 44,6\% (1 sampai 3 kali bahkan ada yang sudah 16-19 kali punya pacar (1,7\%). Mereka meyatakan bertemu dengan pacar dapat dimana saja, umumnya lokasi menghabiskan waktu dengan pacar dapat di rumah $(51,4 \%)$ dan sekolah $(18,8 \%)$ rata-rata mereka menghabiskan waktu 2 jam $(33,1 \%)$ dan 1 jam $(28,6 \%)$.

Hasil tersebut patut kita waspadai karena dalam kehidupan moral, seiringan dengan bekerjanya gonads, tak jarang timbul konflik dalam diri remaja. Masalah yang timbul yaitu akibat adanya dorongan seks dan pertimbangan moral sering kali bertentangan dan hal inilah yang menyebabkan remaja sangat perlu untuk berdiskusi karena apa yang sedang atau dialami seseorang akan mempengaruhi pengahayatan terhadap stimulus sosial (sarwono, 2008).

Hasil perilaku penyimpangan seksual remaja yang paling mengkhawatirkan dari penelitian ini adalah ternyata siswa-siswi $10,9 \%$ pernah melakukan onani atau masturbasi bahkan mereka pun menginginkan mempunyai kekasih yang sesama jenis $(5,1 \%)$ walaupun hasil tersebut hanya sebagian kecil tapi hal ini sudah merupakan perilaku yang harus kita benahi bersama terutama keluarga dan lingkungan pendidikan. Hal ini dapat dihubungkan 
menurut WHO dibeberapa negara yang memperlihatkan adanya informasi yang baik dan benar dapat menurunkan permasalahan reproduksi pada remaja. Dengan demikian dapat dikatakan bahwa semakin tinggi pengetahuan remaja maka akan semakin baik perilakunya, karena pengetahuan atau kognitif merupakan domain yang sangat penting untuk terbentuknya tindakan seseorang (overt behavior).

Menurut Notoatmodjo (2007) bahwa perilaku yang didasari oleh pengetahuan akan lebih langgeng daripada perilaku yang tidak didasari pengetahuan. ada beberapa faktor yang mempengaruhi pengetahuan seseorang antara lain adalah pendidikan dan informasi

Hasil penelitian memperlihatkan telah terkikisnya rasa malu pada diri sebagian remaja. Salah satu penyebab degradasinya moral remaja yaitu pornografi yang dengan mudah dapat diakses. Paparan pornografi telah memberikan pengaruh terhadap jumlah remaja yang teridentifikasi mengalami penyimpangan seksual. Bangunan moral remaja dapat diluluhlantakkan dengan mudah oleh pornografi. Menurut Isti $(2004 ; 19)$ nafsu merupakan sumber energi yang mengerakkan manusia ke arah sifat kebinatangan. Namun Allah SWT menciptakan rasa malu dan akal untuk memelihara sifat kemanusiaan. Dengan akalnya, manusia dapat mengendalikan nafsu untuk meningkatkan kualitas hidup.

Penanaman landasan agama kepada remaja sejak mereka kanak-kanak merupakan upaya sungguh-sungguh yang dapat dilakukan orangtua untuk membentengi hati, pikiran dan perilaku remaja dari perilaku seksual yang menyimpang. Menurut Sudarsono (2004; 119) agama merupakan peraturan berdimensi vertikal dan horizontal dari Tuhan Yang Mahaesa yang mampu memberi dorongan terhadap jiwa manusia yang berakal agar berpedoman menurut peraturan Tuhan dengan kehendaknya sendiri tanpa dipengaruhi. Lingkungan sekitar dapat memberikan dampak yang sangat besar terhadap sikap remaja terhadap kesehatan reproduksi. Peran orangtua, masyarakat dan guru sebagai pembimbing sangat dibutuhkan dalam hal ini untuk mencegah perilaku penyimpangan seksual pada remaja.

\section{SIMPULAN}

Hasil penelitian menunjukkan sebanyak $70 \%$ remaja perempuan di Bekasi menjaga perilaku kesehatan reproduksinya masing-masing sedangkan 57\% laki-laki memperhatikan perilaku kesehatan reproduksinya. Hasil penelitian terkait perilaku penyimpangan seksual remaja yaitu terdapat $10,9 \%$ remaja sekolah pernah melakukan onani atau masturbasi dan 5,1\% diantara mereka menginginkan mempunyai kekasih yang sesama jenis.

\section{UCAPAN TERIMAKSIH}

Peneliti mengucapkan terimakasih kepada pihak-pihak yang telah membantu terlaksananya penelitian ini, khusunya pihak sekolah yang telah memberikan kesempatan peneliti untuk mendapatkan data, lembaga penelitian UHAMKA.

\section{DAFTAR PUSTAKA}

Al-Hafidz, W. Ahsin. 2010. Fikih Kesehatan. Jakarta: Amzah.

Badan Pusat Statistik. 2013. Proyeksi Penduduk Indonesia 2010-2035. Jakarta: Badan Pusat Statistika.

BKKBN. 2006. Buku Saku Bagi Petugas Lapangan Program KB Nasional Materi Konseling. Jakarta: BKKBN

BKKBN. 2005. Tumbuh Kembang Remaja. [Serial Online]. http://hqweb01.bkkbn.go.id/ 
hqweb/ceria/mb2tumbuhkembang.ht $\underline{\mathrm{ml}}$.

Departemen Kesehatan RI . 2003. Materi Pelayanan Kesehatan Peduli Remaja $(P K P R)$. Jakarta: Dirjen Bina Kesehatan Masyarakat.

Hurlock, 2003. Psikologi Perkembangan. Jakarta: Erlangga.

Isti, Badiatul M. 2004. Remaja Dirantai Birahi (Kupas Tuntas Pornografi dalam Perspektif Islam). Bandung: Pustaka Ulumudin.

KBBI. 2017. Sikap. Diakses: 8 Agustustus 2017. https://kbbi.web.id/

Monks. 2009. Tahap Perkembangan Masa Remaja. New Jersey: Medical Journal.

Muagman. 1980. Definisi Remaja. Jakarta: Penerbit Grafindo Jakarta.

Notoadmodjo soekidjo. 2003. Pendidikan dan perilaku kesehatan.jakarta : Rineka Cipta.
Notoadmodjo Soekidjo.2007. Konsep Perilaku Dan Perilaku Kesehata dalam promosi kesehatan dan ilmu perilaku. Jakarta: rineka cipta.

Politekhnik Kesehatan, 2010. Remaja Cenderung Bebas Dalam Masyarakat. Modul Kesehatan Reproduksi Remaja

Sarwono, 2003. Pendidikan dan Perilaku Seksual Pranikah. Edisi Revisi, Jakarta: Penerbit Grafindo Jakarta.

Rinawati. 2012. Kesehatan Keluarga. Jakarta: Tugu Publisher.

Sarwono, 2008. Psikologi Remaja. Jakarta: PT Raja Grafindo Persada.

Sarwono. 2006. Pelayanan Kesehatan Maternal dan Neonatal. Jakarta: YBP - SP.

Sudarsono, 2004. Kenakalan Remaja. Jakarta: PT. Rineka Cipta.

Widyastuti, Yani dkk. 2009. Kesehatan Reproduksi. Yogyakarta: Fitramaya. 